\title{
Springer
}

\section{Development and validation of a Mass Spectrometry binding assay for mGlu5 receptor}

\begin{tabular}{|c|c|}
\hline Journal: & Analytical and Bioanalytical Chemistry \\
\hline Manuscript ID & $A B C-00846-2020$ \\
\hline Type of Paper: & Research Paper \\
\hline $\begin{array}{r}\text { Date Submitted by the } \\
\text { Author: }\end{array}$ & 28-Apr-2020 \\
\hline Complete List of Authors: & $\begin{array}{l}\text { Llebaria, Amadeu; aMCS, Laboratory of Medicinal Chemistry \& Synthesis, } \\
\text { Department of Biological Chemistry, Institute for Advanced Chemistry of } \\
\text { Catalonia (IQAC-CSIC) } \\
\text { Ricart-Ortega, Maria; aMCS, Laboratory of Medicinal Chemistry \& } \\
\text { Synthesis, Department of Biological Chemistry, Institute for Advanced } \\
\text { Chemistry of Catalonia (IQAC-CSIC) } \\
\text { Berizzi, Alice; IGF } \\
\text { Catena, Juanlo; aMCS, Laboratory of Medicinal Chemistry \& Synthesis, } \\
\text { Department of Biological Chemistry, Institute for Advanced Chemistry of } \\
\text { Catalonia (IQAC-CSIC); bSIMchem, Service of Synthesis of High Added } \\
\text { Value Molecules, Institute for Advanced Chemistry of Catalonia (IQAC- } \\
\text { CSIC), Barcelona, Spain } \\
\text { Malhaire, Fanny; IGF } \\
\text { Muñoz, Lourdes; aMCS, Laboratory of Medicinal Chemistry \& Synthesis, } \\
\text { Department of Biological Chemistry, Institute for Advanced Chemistry of } \\
\text { Catalonia (IQAC-CSIC); bSIMchem, Service of Synthesis of High Added } \\
\text { Value Molecules, Institute for Advanced Chemistry of Catalonia (IQAC- } \\
\text { CSIC), Barcelona, Spain } \\
\text { Serra, Carme; aMCS, Laboratory of Medicinal Chemistry \& Synthesis, } \\
\text { Department of Biological Chemistry, Institute for Advanced Chemistry of } \\
\text { Catalonia (IQAC-CSIC); bSIMchem, Service of Synthesis of High Added } \\
\text { Value Molecules, Institute for Advanced Chemistry of Catalonia (IQAC- } \\
\text { CSIC), Barcelona, Spain } \\
\text { Lebon, Guillaume; IGF } \\
\text { Goudet, Cyril; IGF }\end{array}$ \\
\hline Keywords: & $\begin{array}{l}\text { HPLC, Mass spectrometry / ICP-MS, Bioanalytical methods, Drug } \\
\text { monitoring / Drug screening, Pharmaceuticals, Radiochemical methods }\end{array}$ \\
\hline
\end{tabular}

\section{SCHOLARONE




\title{
Analytical Bioanalytical Chemistry
}

Main Manuscript for:

\section{Development and validation of a Mass Spectrometry binding assay for mGlu5 receptor}

\begin{abstract}
Maria Ricart-Ortegaa ${ }^{a, c}$, Alice E. Berizzic ${ }^{c}$, Juanlo Catena ${ }^{a}$, Fanny Malhaire ${ }^{c}$, Lourdes Muñoz ${ }^{a, b}$, Carmen Serraa,b, Guillaume Lebonc, Cyril Goudetc ${ }^{,{ }^{*}}$ and Amadeu Llebariaa, ${ }^{a}$
\end{abstract}

aMCS, Laboratory of Medicinal Chemistry \& Synthesis, Department of Biological Chemistry, Institute for Advanced Chemistry of Catalonia (IQAC-CSIC), Barcelona, Spain; 'SIMchem, Service of Synthesis of High Added Value Molecules, Institute for Advanced Chemistry of Catalonia (IQAC-CSIC), Barcelona, Spain; 'IGF, CNRS, INSERM, University of Montpellier, F-34094 Montpellier, France.

${ }^{*}$ Amadeu Llebaria (ORCID: 0000-0002-8200-4827) and Cyril Goudet (ORCID: 0000-0002-8255-3535)

Email: amadeu.llebaria@iqac.csic.es and cyril.goudet@igf.cnrs.fr

\begin{abstract}
Mass spectrometry (MS) binding assays are a label-free alternative to radioligand or fluorescence binding assays, so the readout is based on direct mass spectrometric detection of the test ligand. The study presented here describes the development and validation of a highly sensitive, rapid and robust MS binding assay for the quantification of the binding of the metabotropic glutamate 5 (mGlu5) negative allosteric modulator (NAM), MPEP (2-Methyl-6-phenylethynylpyridine) at the mGlu5 allosteric binding site. The LC-ESI-MS/MS (Liquid Chromatography - Electrospray Ionization - Tandem Mass Spectrometric) analytical method was established and validated with a deuterated analogue of MPEP as an internal standard. The developed MS binding assay described here allowed for the determination of MS binding affinity estimates that were in agreement with affinity estimates obtained from a tritiated MPEP radioligand saturation binding assay; indicating the suitability of this methodology for determining affinity estimates for compounds that target mGlu5 allosteric binding sites.
\end{abstract}

\section{Keywords}

MPEP, mGlu5 receptor, MS binding assays, radioligand binding assays, saturation assay

\section{Introduction}


Understanding and quantifying the binding kinetics of ligand-target interactions is critical to any carefully considered drug discovery project [1-5]. To date, conventional methods for measuring 5 drug-receptor binding interactions are based on competitive assays requiring radiolabeled [6-7] or fluorescently labeled ligands [8] that can be quantified with high sensitivity. Despite the robustness of radioligand binding assays, they

10 carry some inherent drawbacks in terms of safety precautions, expensive synthesis, special lab requirements and waste disposal. Alternatively, the addition of fluorescent moieties to ligands considerably modifies its chemical structure, which

15 may affect their pharmacological properties and their synthesis can be challenging and costly. In many cases, the protein being investigated also needs to be altered to allow for the measurement of FRET (Förster resonance energy transfer) 20 between a donor (the ligand's fluorescent scaffold) and an acceptor (the fluorophore attached to the target), which can lead to additional complications [9]. These approaches have been applied successfully to many different receptors, but

25 assays have not been developed for all target proteins [10].

The development of mass spectrometry (MS) binding assays by several teams attempts to circumvent some of these limitations by directly 30 measuring the binding kinetics of a ligand of interest to its target receptor in conditions that are more physiologically relevant [11-23]. In this way, the quantification of binding estimates for a ligand by the MS binding technique does offer some 35 advantages over conventional radioligand and fluorescent binding techniques. Alike with labeled ligands though, ligands for MS binding are still required to fulfill a set of criteria to allow for accurate detection in an assay. Ligands should 40 have high affinity and selectivity for their target and have low non-specific binding. The compound should have appropriate physicochemical properties to allow for suitable atmospheric ionization and quantification by HPLC-MS (High 45 Pressure Liquid Chromatography - Mass Spectrometry) with high sensitivity.

The metabotropic glutamate 5 receptor (mGlu5) is one of eight mGlu receptors that belongs to the class C G protein-coupled receptor (GPCR) family, 50 which preferentially couple to $G_{q / 11}$ proteins [24]. Its essential role in regulating neuronal synaptic activity identifies the mGlu5 as an important therapeutic target in neurological and psychiatric disorders such as Alzheimer's disease, pain, 55 depression and schizophrenia [25-27]. To date, a number of allosteric modulators are available for targeting the mGlu5 [27-31]. They offer greater opportunity for selectivity at a receptor subtype owing to their ability to target a topographically

60 distinct and non-overlapping allosteric site to that of the orthosteric (endogenous) ligand binding site, which tends to be less well conserved [27-28].

In this study, we report the development and validation of a label-free MS binding assay for the 65 mGlu5 receptor, which allows for the investigation of the binding kinetics of mGlu5 allosteric ligands that target the common allosteric site, without the need of a competing ligand. To allow for a straightforward validation of the MS binding assay,

70 we employed a ligand that has already been validated as a radioligand, namely, 2-Methyl-6(phenylethynyl)pyridine (MPEP) - a potent mGlu5 negative allosteric modulator (NAM) [32-33]. This study describes the first equilibrium saturation MS

75 binding assay for MPEP at the mGlu5. To achieve this aim, MCS0455, a deuterated derivative of MPEP, was synthesized to serve as an internal standard (IS). We developed a LC-ESI-MS/MS (Liquid Chromatography - Electrospray lonization 80 Tandem Mass Spectrometric) method for the 
quantification of MPEP, MCS0455 and VU0409106, a competing mGlu5 allosteric ligand [34] required for the determination of non-specific binding (Figure 1). This method was analytically 85 validated and the MS binding estimates were compared to $\left[{ }^{3} \mathrm{H}\right] \mathrm{MPEP}$ saturation radioligand binding estimates.

\section{Results and Discussion}

\section{Synthesis of MCS0455}

90 The synthesis of MCS0455 is outlined in scheme 1. The mono $\mathrm{Br} / \mathrm{Li}$ exchange reaction of 2,6dibromopyridine (4) with $n$-Buthyllithium followed by reaction with deuterated iodomethane $\left(C_{3} \mathrm{I}\right)$ provided the monoalquilated pyridine 5 [36]. Then, 95 compound 5 reacted with the triple bond of the ethynylbenzene via a Sonogashira cross-coupling reaction to give MCS0455 (2).

\section{LC-ESI-MS/MS analytical method development}

A LC-ESI-MS/MS method was initially developed 100 enabling MPEP, MCS0455 and VU0409106 quantification in the picomolar range. For the HPLC method development, various isocratic and gradient HPLC methods were evaluated to obtain suitable retention times and appropriate peak 105 shapes. A gradient HPLC method was set as detailed in the "Materials and Methods" section. The influence of $\mathrm{pH}(3.0-10.0)$ of the aqueous component of the mobile phase on retention time and signal intensity of MPEP, MCS0455 and 110 VU0409106 in LC-ESI-MS chromatograms recording m/z 194.1, m/z 197.1 and m/z 331.1 was studied.

Three different acidic and basic mobile phases were tested (10 mM ammonium formate, $\mathrm{pH} 3.0$,

$11510 \mathrm{mM}$ ammonium bicarbonate, $\mathrm{pH} 7.0$ and $10 \mathrm{mM}$ ammonium formate, $\mathrm{pH}$ 10.0) for solvent $A$ in combination with acetonitrile as solvent B. Signal intensity of MPEP, MCS0455 and VU0409106 was influenced by the $\mathrm{pH}$ of different mobile phases
120 (Figure 2A). MPEP and MCS0455 retention times were not modified. In contrast, the retention time of VU0409106 was reduced under basic conditions (Figure 2B). Therefore, $10 \mathrm{mM}$ ammonium bicarbonate at $\mathrm{pH} 7.0$ was chosen as solvent $\mathrm{A}$ 125 and acetonitrile was chosen as solvent $B$, since the peak intensity for all the compounds was increased under these elution conditions. The effect of the injection volume was also studied, 100 $\mu \mathrm{L}$ was selected since it resulted in a larger signal 130 to noise (SN) ratio. However, this injection volume affected retention times and resulted in a split of the VU0409106 peak. For optimized HPLC conditions, the resulting retention times of MPEP, MCS0455 and VU0409106 were $2.78 \mathrm{~min}, 2.75$ $135 \mathrm{~min}$ and 0.34/2.06 min, respectively (Figure 3A-C). The total run time was 9 min per sample.

Optimization of ESI-MS/MS compound-dependent parameters for precursors and product ions of MPEP, MCS0455 and VU0409106 was performed 140 by infusion of a $0.01 \mathrm{mg} \mathrm{ml}^{-1}$ solution, dissolved in water:acetonitrile at ratio of 1:3. Our first aim was then to identify the most abundant product ions of the $[\mathrm{M}+\mathrm{H}]^{+}$parent ion of MPEP $(\mathrm{m} / \mathrm{z}$ 194.1), MCS0455 (m/z 197.1) and VU0409196 (m/z 145331.1 ), respectively. After that, the MS/MS fragmentation was carried out. The most abundant fragments observed were $\mathrm{m} / \mathrm{z} 152 \pm 6$ and $165 \pm 8$ for MPEP, m/z $152 \pm 6$ and $168 \pm 8$ for MCS0455 and $\mathrm{m} / \mathrm{z} 216 \pm 2$ and $313 \pm 2$ for VU0409106, 150 respectively (Figure 3D-F). The optimal source parameters, the compound dependent parameter, normalized collision energy (CE) and the compound dependent parameter, normalized Act $Q$ and Act Time were established for each MS/MS 155 transition as described in "Materials and Methods" section.

\section{LC-ESI-MS/MS analytical method validation}


The established LC-ESI-MS/MS method was validated as detailed in the "Materials and 160 Methods" section. Since interfering peaks from matrix samples were not observed at the retention times corresponding for MPEP, MCS0455 and VU0409106 it was considered that the assays were selective. The linearity was evaluated on four

165 separate days with two sets of calibration curves per day showing good reproducibility. The correlation coefficients $\left(R^{2}\right)$ of the plotted calibration curves were higher than 0.999 . The lowest concentration of analyte in a sample which 170 can be quantified reliably, with an acceptable accuracy and precision - the lower limit of quantification (LLOQ) - was confirmed to be 0.125 $\mathrm{nM}$ for MPEP and MCS0455, and $0.35 \mathrm{nM}$ for VU0409106 (Table 1 and Supplementary Table 1-

1752 ). No carry over peaks were observed following the injection of the calibration curve points.

LC-ESI-MS/MS within-run and between run accuracy and precision were evaluated for each quality control (QC) sample of MPEP, MCS0455

180 and VU0409106 and they satisfied the indicated criteria (Table 1 and Supplementary Table 1-2). Technician within-run and between-run accuracy and precision levels were also assessed, and RE (relative error) and RSD (relative standard 185 deviation) values were lower than $\pm 20 \%$ for all the QC samples of analytes (Table 1 and Supplementary Table 1-2).

The matrix factor of MPEP was obtained at 0.35 nM (Lower; L), $10 \mathrm{nM}$ (Medium; M) and $20 \mathrm{nM}$ 190 (Higher; H) as explained in "Materials and Methods" section. The RSD of the IS-normalized matrix factor calculated from the 3 lots of matrix was $10.9 \%$ for $L, 5.7 \%$ for $M$ and $1.9 \%$ for $H$. The extraction recoveries of MPEP, MCS0455 and 195 VU0409106 were consistent and reproducible for each QC (Table 2).

\section{MS binding assay development}

The protocol for the MS binding assays was designed with the following workflow: incubation,

200 separation of target-bound complex from unbound ligand by aspiration, liberation by protein denaturation and analysis through the validated HPLC-MS/MS methodology (Figure 4). By following the different setups established by

205 Wanner et al, multiple parameters were studied in order to optimize assay conditions [10-19].

By using human (h)mGlu5 transiently transfected HEK 293T cells in preliminary experiments, different 96-well filter plate pre-treatment

210 conditions (water or $0.1-1 \%$ polyethyleneimine) were tested for their ability to reduce non-specific binding. By selecting $0.5 \% \quad \% \quad(\mathrm{~m} / \mathrm{v})$ polyethyleneimine (PEI) as the pre-treatment condition this resulted in reduced non-specific

215 binding and the largest window between TB (total binding) and NSB (non-specific binding) (data not shown). The effect of different elution solvents, including 100\% methanol, $75 \%$ acetonitrile and $25 \%$ ammonium formate buffer $(5 \mathrm{mM}, \mathrm{pH} 10)$ or $22075 \%$ acetonitrile and $25 \%$ ammonium bicarbonate buffer $(10 \mathrm{mM}, \mathrm{pH} 7)$, was also assessed to maximise ligand recuperation. Recovery of bound ligand and reproducibility between experiments was increased by elution with acetonitrile $(3 \times 100$ $225 \mu \mathrm{L} /$ well) and $10 \mathrm{mM}$ ammonium bicarbonate buffer, pH 7 ( 1 x $100 \mu \mathrm{L} /$ well) (see Supplementary Figure 1). The effect of filtration or centrifugation on the last step of the standard setup was also assessed to improve compound recovery. This involved the

230 addition of $100 \mu \mathrm{L}$ of aqueous solvent per well to plates prior to filtration (30 s aspiration step) or centrifugation (10 min, $2000 \mathrm{rpm}, 4^{\circ} \mathrm{C}$ ) before the samples were analysed by the HPLC-MS/MS method. Since recovery techniques showed no

235 significant differences between MPEP saturation isotherms, the filtration technique was chosen for the remainder of the experiments as it is rapid and 
allows for higher throughput of samples (Supplementary Figure 2).

240 To reduce the variability observed between membranes prepared from different batches of transiently transfected cells, a stably, inducible hmGlu5 expressing HEK293 cell line was generated. In those cells, the level of hmGlu5

245 expression following induction with doxycycline is highly reproducible. Following optimization of conditions, the experiments were then performed with membranes prepared from this cell line. In all cases, an IS was added to samples to correct for 250 the loss of analyte during sample preparation. To prevent ligand depletion, all remaining studies used $20 \mu \mathrm{g}$ of hmGlu5 expressing membranes per well in a final incubation volume of $300 \mu \mathrm{L}$.

\section{Saturation MS binding assay}

255 The validated LC-ESI-MS/MS method was used for the quantification of MPEP, MCS0455 and VU0409106 in an hmGlu5 MS saturation binding assay. We, therefore, describe the first saturation MS binding experiment with MPEP as a native 260 marker for hmGlu5. Total and non-specific binding of MPEP at the hmGlu5 was determined (Figure $5 A$ ), and by calculating the difference of these values specific MPEP binding was determined (Figure 5B). This allowed for the calculation of a $K_{D}$ 265 (equilibrium dissociation constant) value of $13.16 \pm$ $1.24 \mathrm{nM}$ and a $\mathrm{B}_{\max }$ (maximum amount of binding sites) value of $18.53 \pm 2.67 \mathrm{pmol} / \mathrm{mg}$ protein. MS binding results were in agreement with the affinity estimate $\left(\mathrm{K}_{\mathrm{D}}=3.65 \pm 0.32 \mathrm{nM}\right)$ obtained in

$270\left[{ }^{3} \mathrm{H}\right] \mathrm{MPEP}$ radioligand saturation binding assay for the same receptor (Supplementary Figure and Table 3) and to a $K_{D}$ value reported in the literature for [ $\left.{ }^{3} \mathrm{H}\right] \mathrm{MPEP}$ at the hmGlu5 receptor [37].

\section{Materials and methods}

\section{Materials}

All chemicals and solvents were from commercial suppliers and used without purification, with the exception of the anhydrous solvents such as dimethylformamide (DMF), which were treated

280 previously through a system of solvent purification (PureSolv), degasified with inert gases and dried over alumina or molecular sieves. HEK 293T and HEK 293 cells were obtained from cell culture service (IQAC-CSIC, Barcelona, Spain) and 285 ATCC ${ }^{\circ}$ CRL1573 ${ }^{\mathrm{TM}} \quad$ (Molsheim, France), respectively. Dulbecco's modified Eagle medium (DMEM), Opti-MEM I reduced serum media, trypsin and fetal bovine serum were purchased from Thermo Fisher Scientific. Antibiotics were 290 purchased from Sigma-Aldrich, except blasticidin and hygromycine $B$ from InvivoGen. Polyethylenimine (PEI) and X-tremeGENE 9 were purchased from Sigma-Aldrich and Roche, respectively. VU0409106 was obtained from Tocris

295 Biosciences.

\section{Methods}

\section{Synthesis of MCS0455}

Reactions were monitored by thin layer chromatography (60 F, 0.2 mm, Macherey-Nagel) 300 by visualization under 254 and/or $365 \mathrm{~nm}$ lamp. Purification was made by flash column chromatography by using Panreac silica gel 60, 40-63 microns RE or by Isolera-Biotage equipment (SNAP KP-C18-HS-12g column; A: $0.05 \%$ formic 305 acid in water and $B: 0.05 \%$ formic acid in acetonitrile; 5 \% B 3 column volume (CV), 5 \% B 100 \% B 18 CV, 100 \% B 5 CV). Nuclear magnetic resonance (NMR) spectrometry was performed using a Varian Mercury $400 \mathrm{MHz}$. Chemical shifts

$310 \delta$ are reported in parts per million (ppm) against the reference compound (Chloroform $\delta=7.26$ ppm $\left({ }^{1} \mathrm{H}\right), \delta=77.16 \mathrm{ppm}\left({ }^{13} \mathrm{C}\right)$, and $\mathrm{DMSO}_{6} \delta=$ 2.50ppm $\left({ }^{1} \mathrm{H}\right), \quad \delta=39.52$ ppm $\left.\left({ }^{13} \mathrm{C}\right)\right)$. HPLC analysis was performed on a 2795 Alliance HPLC 
315 system (Waters) equipped with an 1100 diode array detector (Agilent). Chromatographic separations were performed with a Zorbax Extend C18 column $(2.1 \times 50 \mathrm{~mm}, 3.5 \mu \mathrm{m}$, Agilent $)$ with a Zorbax Extend C18 pre-column (2.1 x $12.5 \mathrm{~mm}, 5$ $320 \mu \mathrm{m}$, Agilent). The mobile phase used was a mixture of solvent $A$ ( $0.05 \%$ formic acid in water) and solvent $B(0.05 \%$ formic acid in acetonitrile) with a flow rate of $0.5 \mathrm{~mL} / \mathrm{min}$. The initial mobile phase composition was $5 \%$ solvent $B$ and these

325 conditions were maintained for $0.5 \mathrm{~min}$. Conditions were changed to $100 \%$ solvent $B$ (over $5 \mathrm{~min}$ ) and these conditions were maintained for $2 \mathrm{~min}$, before the return of the initial conditions. For all experiments, $10 \mu \mathrm{L}$ of sample - diluted in

330 acetonitrile - was injected and MS detection was carried out on a Quattro micro triple quadrupole mass spectrometer (Waters), using ESI source in positive ion mode. Melting points were measured with Melting Point B-545 (Büchi), ramp $0.5^{\circ} \mathrm{C} / \mathrm{min}$ 335 with digital temperature measurement.

2-Bromo-6-methyl-d $d_{3}$-pyridine (5). 2,6Dibromopyridine (4) (1.07 g, $4.53 \mathrm{mmol})$ was dissolved in tetrahydrofuran (THF) $(1.3 \mathrm{~mL})$ and the solution was cooled to $-78^{\circ} \mathrm{C}$, followed by slow 340 addition of BuLi $2.5 \mathrm{M}$ in hexane $(0.186 \mathrm{~mL}, 4.65$ $\mathrm{mmol})$. The mixture was stirred for $1 \mathrm{~h}$ at $78^{\circ} \mathrm{C}$, followed by addition of iodomethane- $d_{3}(0.79 \mathrm{~g}$, $5.44 \mathrm{mmol})$. Then, the reaction mixture was warmed to room temperature and stirred for $1 \mathrm{~h}$.

345 The reaction was then quenched with $10 \mathrm{~mL}$ of water, and extracted with $3 \times 10 \mathrm{~mL}$ ethyl acetate (EtOAc). The resulting organic phases were combined, dried over anhydrous $\mathrm{Na}_{2} \mathrm{SO}_{4}$, filtered and evaporated. The residue was purified by flash 350 column chromatography with dichloromethane; yielding $140 \mathrm{mg} \mathrm{(16 \% )} \mathrm{of} \mathrm{the} \mathrm{desired}$ compound. ${ }^{1} \mathrm{H}$ NMR $\left(400 \mathrm{MHz}, \mathrm{CDCl}_{3}\right) \delta 7.42 \mathrm{td}(\mathrm{t}$, $J=7.6,1 \mathrm{H}), 7.29(\mathrm{dd}, J=7.6,0.9 \mathrm{~Hz}, 1 \mathrm{H}), 7.10$ (dd, $J=7.6,0.9 \mathrm{~Hz}, 1 \mathrm{H}$ ) [27].
355 2-Methyl- $d_{3}-6$-phenylethynylpyridinehydrochlo-

ride (2). To a suspension of 2-bromo-6-methyl- $d_{3}$ pyridine (5) $(140 \quad \mathrm{mg}, \quad 0.80 \quad \mathrm{mmol})$, bis(triphenylphosphine)palladium (II) dichloride (46.2 $\mathrm{mg}, 0.04 \mathrm{mmol}$ ) and copper iodide $(7.6 \mathrm{mg}$, $3600.04 \mathrm{mmol}$ ), in $1.5 \mathrm{~mL}$ of anhydrous DMF, previously purged with argon, 1-ethynylbenzene $(0.097 \mathrm{~mL}, 0.80 \mathrm{mmol})$ and dry triethylamine $(0.33$ $\mathrm{mL}, 2.4 \mathrm{mmol}$ ) were added, and the reaction mixture was stirred at $40^{\circ} \mathrm{C}$ for $8 \mathrm{~h}$. After, $40 \mathrm{~mL}$ of 365 EtOAc was added to the mixture, and was washed with $40 \mathrm{~mL}$ of saturated solution of $\mathrm{NaHCO}_{3}$ and $40 \mathrm{~mL}$ of brine. The organic layer was dried over $\mathrm{Na}_{2} \mathrm{SO}_{4}$, filtered and evaporated under vacuum. The remaining residue was purified via flash 370 column chromatography with EtOAc-hexane (1:4). A pale brown solid was isolated (100 mg, $53 \%$ ). A portion of this compound was dissolved in diethyl ether and $4 \mathrm{M} \mathrm{HCl} /$ dioxane was added, the precipitate was collected by filtration to give the 375 hydrochloride salt as a brown solid. ${ }^{1} \mathrm{H}$ NMR (400 $\left.\mathrm{MHz}, \mathrm{DMSO}-d_{6}\right) \delta 8.21$ (t, $\left.J=8 \mathrm{~Hz}, 1 \mathrm{H}\right), 7.84$ (d, $J$ $=8 \mathrm{~Hz}, 1 \mathrm{H}), 7.72-7.64(\mathrm{~m}, 3 \mathrm{H}), 7.56-7.43(\mathrm{~m}$, $3 \mathrm{H}) .{ }^{13} \mathrm{C}$ NMR (101 MHz, DMSO- $\left.d_{6}\right)$ 8156.90, $143.20,136.30,132.53,131.03,129.46,126.92$, 380 126.42, 120.54, 96.18, 84.13, 20.38. HRMS (m/z): $[\mathrm{M}+\mathrm{H}]^{+}$calculated for $\mathrm{C}_{14} \mathrm{D}_{3} \mathrm{H}_{8} \mathrm{~N}, 197.1177$; found, 197.1178. HPLC/DAD: purity $($ abs $=254 \mathrm{~nm})=$ $100 \%$; RT $=2.44$ min. m.p. $130.5-132.3^{\circ} \mathrm{C}$

\section{LC-ESI-MS/MS}

385 Chromatographic and mass spectrometric conditions

Chromatographic separations were accomplished on a Zorbax Extend C18 column $(2.1 \times 50 \mathrm{~mm}, 3.5$ $\mu \mathrm{m}$, Agilent) with a Zorbax Extend C18 precolumn 390 (2.1 x 12.5 mm, $5 \mu \mathrm{m}$, Agilent). HPLC analysis was performed on a Thermo Scientific Dionex UltiMate 3000 High-Performance Liquid Chromatography system equipped with a pump (LPG-3400SD), an 
auto-sampler (ACC-3000T) with a thermostated 395 column compartment. Gradient HPLC method was used for the analysis of MPEP, the internal standard (IS), MCS0455, and VU0409106. The mobile phase consisted of solvent A $(10 \mathrm{mM}$ ammonium bicarbonate $\mathrm{pH} 7$ ) and solvent $\mathrm{B}$ 400 (acetonitrile) with a flow rate of $0.9 \mathrm{~mL} / \mathrm{min}$. The initial mobile phase composition was $20 \%$ solvent $\mathrm{B}$, changed progressively to $100 \%$ for $4 \mathrm{~min}$. Following $2 \mathrm{~min}$ under these conditions, the initial conditions were reinstated within $1 \mathrm{~min}$, and then 405 were maintained to allow for column equilibration for $2 \mathrm{~min}$. The column temperature was set to $40^{\circ} \mathrm{C}$, the sampler temperature was established to $10^{\circ} \mathrm{C}$ and the injection volume was $100 \mu \mathrm{L}$.

Mass spectrometry detection was carried out on 410 an LTQ XL ion trap mass spectrometer (Thermo Scientific), using ESI source in positive ion mode. Quantification was performed using single reaction monitoring (SRM) mode with the transition of $\mathrm{m} / \mathrm{z}$ $194.1 \rightarrow 152 \pm 6,165 \pm 8$ for MPEP, $\mathrm{m} / \mathrm{z} 197.1 \rightarrow$ $415152 \pm 6,168 \pm 8$ for MCS0455 and m/z $331.1 \rightarrow$ $216 \pm 2,313 \pm 2$ for VU0409106. The optimal source parameters were as follows: sheath gas flow at 60 , aux gas flow at 10 , sweep gas flow at 10 , capillary temperature at $300^{\circ} \mathrm{C}$, source voltage 420 at $3 \mathrm{kV}$, capillary voltage at $1 \mathrm{~V}$ and tube lens at 35 V. The compound dependent parameter normalized collision energy (CE) was set at $65 \%$ for MPEP and MCS0455 and $30 \%$ for VU0409106. The compound dependent parameter 425 normalized Act $Q$ was set at $0.6 \%$ for MPEP and MCS455 and $0.25 \%$ for VU0409106. The compound dependent parameter Act Time was set at $40 \mathrm{~ms}$ for MPEP and MCS0455 and $30 \mathrm{~ms}$ for VU0409106. The wideband activation option was 430 selected. System control was performed by Thermo Xcalibur 2.2 software (Thermo Scientific).

\footnotetext{
Preparation of calibration curve and quality control samples
}

The calibration standard curves of MPEP, 435 MCS0455 and VU0409106 with final concentrations of $0.125-25 \mathrm{nM}$ were obtained from working solutions (1 - $50 \mathrm{nM})$ by further dilution with acetonitrile : $10 \mathrm{mM}$ ammonium bicarbonate $\mathrm{pH} 7$ (3:1). Working solutions were 440 prepared from previous working standard solutions with concentrations in the range of $10-500 \mu \mathrm{M}$, by dilution of the stock solutions with acetonitrile : 10 $\mathrm{mM}$ ammonium bicarbonate $\mathrm{pH} 7$ (3:1).

Quality control (QC) samples with final 445 concentrations of $0.125 \mathrm{nM}$ or $0.35 \mathrm{nM}$ (Lower limit of quantification; LLOQ), $0.35 \mathrm{nM}$ or $1 \mathrm{nM}$ (Lower; L), $10 \mathrm{nM}$ (Medium; M), $20 \mathrm{nM}$ (Higher; $\mathrm{H}$ ) and 25 nM (Upper limit of quantification; ULOQ) were obtained from working solutions $(2-100 \mathrm{nM})$ by

450 further dilution with acetonitrile: $10 \mathrm{mM}$ ammonium bicarbonate, $\mathrm{pH} 7$ (3:1). Working solutions were prepared in the same way as calibration standards.

\section{Analytical method validation}

455 The Guidance of Industry Bioanalytical Method Validation was adapted to perform a full LC-ESIMS/MS validation process for MPEP, MCS0455 and VU0409106, recommended by FDA [38].

Selectivity of the method was assessed by 460 processing ten blank matrix samples to investigate the potential interferences at the retention times for the analytes and IS compound. Carry over was evaluated by injecting a blank sample after the injection of every calibration curve point. An 465 eleven-point calibration curve was established with concentrations in the range of $0.125-25 \mathrm{nM}$. Calibration curves were built by plotting the peak area of the analyte versus the quantities (in nmol) of the analyte with weighted $\left(1 / x^{2}\right)$ least-squares 470 linear regression. The correlation coefficient $\left(R^{2}\right)$ of calibration curves were more than 0.99 . The backcalculated concentrations at each point were within 
$\pm 20 \%$ of theoretical quantities, except at LLOQ and ULOQ where the calibrator should be $\pm 25 \%$ 475 of the nominal quantities at each validation run.

LC-ESI-MS/MS within-run and between-run accuracy and precision were determined by analyzing six replicates of one sample of each QC on the same day, on three consecutive days. In 480 contrast, technician within-run and between-run accuracy and precision were determined by analyzing five independent samples of each QC on the same day, on three consecutive days. The criteria for the data included accuracy (relative 485 error, RE) within $\pm 20 \%$ (except $\pm 25 \%$ for the LLOQ and ULOQ) and a precision (relative standard deviation, RSD) not exceeding $\pm 20 \%$ ( \pm $25 \%$ for the LLOQ and ULOQ).

For each analyte and the IS, the matrix factor (MF) 490 was calculated for three different hmGlu5 matrix samples at three $Q C$ levels ( $L, M$ and $H$ ), by calculating the ratio of the peak area in the presence of matrix (measured by analyzing blank matrix spiked with analyte after extraction), to the 495 peak area in absence of matrix (analyte only solution). The IS normalized MF should also be calculated by dividing the MF of the analyte by the MF of the IS. The CV of the IS-normalized MF calculated from the 3 samples of matrix should be 500 less than $15 \%$. The extraction recovery was determined at three $Q C$ levels ( $L, M$ and $H$ ) by comparing (in triplicate) the analytical results of extracted samples with corresponding extracts of blanks spiked with the analyte post-extraction.

\section{Generation of HEK 293 stable hmGlu5 inducible cell line}

The stably expressing, inducible hmGlu5 HEK293 cell line was generated with the Flp-In-T-Rex system according to manufacturer

510 recommendations (Invitrogen). Briefly, the cDNA encoding hmGlu5 containing a Flag and SNAP tag in $\mathrm{N}$ terminus (for detection) was inserted into the plasmid pcDNA5-FRT-TO-GFP (Addgene), removing the GFP. This construct was co515 transfected by electroporation with the recombinase plasmid pOG44 (Invitrogen) for a targeted integration of the expression vector to the same locus in Flp-In-T-Rex HEK 293 cells (Invitrogen), ensuring homogeneous levels of gene 520 expression. Cells were grown $48 \mathrm{~h}$ then selected by the addition of $15 \mu \mathrm{g} / \mathrm{mL}$ blasticidin and 100 $\mu \mathrm{g} / \mathrm{mL}$ of hygromycine $\mathrm{B}$. Inducible expression of hmGlu5 was validated following induction with 1 $\mu \mathrm{g} / \mathrm{mL}$ doxycycline (Sigma-Aldrich) by anti-Flag 525 ELISA.

\section{Cell culture and transfections}

The HEK 293T cells and the HEK 293 inducible, stably expressing hmGlu5 cell line were cultured in DMEM supplemented with $10 \%$ FBS and 530 maintained at $37^{\circ} \mathrm{C}$ in a humidified atmosphere with $5 \% \mathrm{CO}_{2}$. $\mathrm{HEK}$ 293T cells were incubated in the presence of $1 \%$ penicillin/streptomycin while, HEK 293 inducible, stably expressing hmGlu5 cells were maintained in the presence of $15 \mu \mathrm{g} / \mathrm{mL}$ 535 blasticidin and $100 \mu \mathrm{g} / \mathrm{mL}$ of hygromycine B. All cells were sub-cultured every two to three days in a 1:3 ratio after reaching $80 \%$ confluence with 5 $\mathrm{mL}$ of trypsin to detach cells, and incubated in a humidified atmosphere at $37^{\circ} \mathrm{C}, 5 \% \mathrm{CO}_{2}$ for 2 - 5 540 min. For transient transfection, 4 million HEK 293T cells were seeded in $100 \mathrm{~mm}$ culture dishes one day before transfection. The next day, HEK 293T cells were transfected with $5 \mu \mathrm{g}$ of hmGlu5 DNA using $15 \mu \mathrm{l}$ of X-tremeGENE 9 diluted in $500 \mu \mathrm{L}$ 545 Opti-MEM 1X. For the inducible, stably expressing hmGlu5 cells, expression of hmGlu5 was induced by the addition of doxycycline at $1 \mu \mathrm{g} / \mathrm{mL}$ in 150 $\mathrm{mm}$ culture dishes containing 15 million cells.

Membrane preparation for MS binding and $550\left[{ }^{3} \mathrm{H}\right] M P E P$ binding assays 
Following $48 \mathrm{~h}$ transfection or $24 \mathrm{~h}$ induction, hmGlu5-HEK cells were grown in 100 or $150 \mathrm{~mm}$ culture dishes and were detached by scraping. Cells were centrifuged at $300 \mathrm{~g}$ for $5 \mathrm{~min}$ and then 555 resuspended in $5 \mathrm{~mL}$ ice-cold homogenization buffer (25 mM HEPES, $10 \mathrm{mM}$ EDTA and $2.5 \mathrm{mM}$ $\mathrm{MgCl}_{2}, \mathrm{pH}$ 7.5). An ultrasonic cell disruptor (SFX 150 , Branson) was then used to homogenize the cell suspension with $3 \times 20 \mathrm{~s}$ bursts, which were 560 separated by $20 \mathrm{~s}$ periods on ice. Cell homogenates were then centrifuged at $600 \mathrm{~g}$ for $10 \mathrm{~min}$ at $4^{\circ} \mathrm{C}$. The supernatant was collected and transferred to a centrifuge tube, the remaining cell pellet was resuspended in homogenization buffer, 565 re-homogenized and centrifuged as previous (this procedure was repeated 3-4 times). The obtained supernatants were combined, and membranes and the cytosolic fraction were separated by ultracentrifugation at $40000 \mathrm{~g}, 4^{\circ} \mathrm{C}$ for $60 \mathrm{~min}$. The 570 pellet was then resuspended in MS binding storage buffer (25 mM HEPES, 1 mM EDTA and $2.5 \mathrm{mM} \mathrm{MgCl}_{2}, \mathrm{pH} 7.5$ ) or [ $\left.{ }^{3} \mathrm{H}\right]$ MPEP binding buffer $\left(110 \mathrm{mM} \mathrm{NaCl}, 5.4 \mathrm{mM} \mathrm{KCl}, 1.8 \mathrm{mM} \mathrm{CaCl}_{2}, 1 \mathrm{mM}\right.$ $\mathrm{MgSO}_{4}, 25 \mathrm{mM}$ glucose, $50 \mathrm{mM}$ HEPES, $58 \mathrm{mM}$ 575 sucrose; $\mathrm{pH} 7.4$ ) to give a final concentration between 1.5 to $2.5 \mathrm{mg} / \mathrm{mL}$ and stored at $-80^{\circ} \mathrm{C}$. Protein concentrations were determined by BCA (bicinchoninic acid) protein assay kit by following the instructions of the supplier.

\section{MPEP saturation MS binding assay}

hmGlu5 expressing membranes ( $20 \mu \mathrm{g} /$ well) were incubated with a range of concentrations of MPEP $(1-100 \mathrm{nM})$ in binding buffer (25 mM HEPES, 100 $\mathrm{mM} \mathrm{NaCl}$ and $2.5 \mathrm{mM} \mathrm{MgCl} 2, \mathrm{pH} 7.5$ ) for $1 \mathrm{~h}$ at $58530^{\circ} \mathrm{C}$, while shaking at $150 \mathrm{rpm}$, in a final assay volume of $300 \mu \mathrm{L} /$ well. The target-ligand complex was separated from the non-binding ligand by rapid vacuum filtration through $1 \mu \mathrm{m}$ GF filter multiwell plate (AcroPrep Advance $350 \mu \mathrm{L}$, Pall
590 Corporation), pre-soaked for $1 \mathrm{~h}$ in $0.5 \% \mathrm{PEI}$, with an extraction plate manifold (Pall Corporation). Samples were washed 3 times with $150 \mu \mathrm{L}$ of icecold binding buffer to eliminate excess non-binding ligand, and the filter plate was dried for $1 \mathrm{~h}$ at $59560^{\circ} \mathrm{C}$. The bound ligand was then recovered by elution with acetonitrile containing the corresponding IS $(3 \times 100 \mu \mathrm{L} /$ well $)$ and $100 \mu \mathrm{L}$ of ammonium bicarbonate buffer $(10 \mathrm{mM}, \mathrm{pH} 7)$ was added to each well, and the solution was

600 aspirated. Samples were then transferred to HPLC vials and analyzed by HPLC-MS/MS methods (see chromatographic and mass spectrometric conditions for more detail). Non-specific binding was determined in the presence of $10 \mu \mathrm{M}$ 605 VU0409106.

\section{$\left[{ }^{3} \mathrm{H}\right]$ MPEP equilibrium saturation binding assay}

hmGlu5 expressing membranes ( $10 \mu \mathrm{g} /$ well) were incubated at $30^{\circ} \mathrm{C}$ for $1 \mathrm{~h}$ with a range of [ $\left.{ }^{3} \mathrm{H}\right]$ MPEP concentrations $(\sim 0.5-25 \mathrm{nM})$ in binding 610 buffer in a final assay volume of $100 \mu \mathrm{L} /$ well. All binding assays were terminated by rapid filtration through $1 \mu \mathrm{m}$ GF multi-well plates (pre-soaked for $1 \mathrm{~h}$ in $0.5 \% \mathrm{PEI}$ ), and 3 washers with ice-cold binding buffer to separate bound and free 615 radioligand. $100 \mu \mathrm{L}$ of scintillant was added to each well. Following $1 \mathrm{~h}$ of incubation, radioactivity was measured on a MicroBeta plate counter. MPEP $(10 \mu \mathrm{M})$ was used to determine non-specific binding in all cases.

\section{Data analysis}

For MPEP saturation MS binding studies, analysis was performed on Thermo Xcalibur 2.2 software (Qual Browser, Thermo Scientific). Obtained peak areas were transformed to $\mathrm{nmol}$ of bound ligand

625 using an appropriate calibration curve, which was based on the peak area of the analyte normalized by the IS compound versus the quantities (in $\mathrm{nmol}$ ) 
of the analyte with weighted $\left(1 / x^{2}\right)$ least-squares linear regression.

630 GraphPad prism version 8 (San Diego, CA) was used for all curve fitting and statistical analysis. For MS and radioligand saturation binding experiments, receptor expression $\left(B_{\max }\right)$ and equilibrium dissociation constants $\left(\mathrm{K}_{\mathrm{A}}\right)$ were 635 determined by applying the following equation to experimental datasets:

$$
Y=\frac{B_{\max }[A]}{[A]+K_{A}}+N S[A]
$$

\section{(Equation 1)}

Where $Y$ represents the bound radioligand, $B_{\max }$ is 640 the total receptor density, $[\mathrm{A}]$ is the ligand concentration, $\mathrm{K}_{\mathrm{A}}$ is the equilibrium dissociation constant of the MPEP and radioligand, and NS represents the non-specific binding of the ligand.

\section{Conclusions}

645 In the present study, we describe the first protocol for a MPEP MS saturation binding assay for the hmGlu5. A sensitive LC-ESI-MS/MS analytical method for detection of MPEP was developed using $\left[{ }^{2} \mathrm{H}_{3}\right]$ MPEP as an internal standard. Its 650 reliability was determined in accordance with FDA guidelines for bioanalytical method validation with respect to selectivity, linearity, lower limit of quantification, accuracy and precision.

A protocol for a MS binding assay was then 655 developed that employs a filtration step for separating excess unbound MPEP from targetbound MPEP, which enabled high throughput of samples. The use of this MS saturation binding assay allowed for the calculation of an affinity 660 estimate of MPEP for its hmGlu5 binding site, which was consistent to the affinity estimate for $\left[{ }^{3} \mathrm{H}\right] \mathrm{MPEP}$ - for the same binding site - as determined by radioligand experiments. Given the consistency of equilibrium dissociation constants 665 between binding assays and those estimates reported in the literature, the established MS binding assay represents a suitable and reliable test system for affinity characterization of test compounds that target the MPEP allosteric binding 670 site of the hmGlu5 receptor. The results described here clearly demonstrate the power of this approach as an alternative to conventional radioligand binding assays.

\section{Acknowledgements}

675 We thank Prof. Jean-Philippe Pin (IGF, University of Montpellier, CNRS, INSERM, Montpellier) for scientific support and contributions to this work. This work was supported by FEDER/Ministerio de Ciencia, Innovación y Universidades - Agencia Estatal de Investigación 680 (CTQ2017-89222-R and PCl2018-093047), by the Catalan government (2017SGR1604), by the CSIC proyectos internacionales de cooperación científica (PICS 2018FR0058) program, by Neuron-ERANET, by the Agence Nationale de la Recherche (ANR-17-NEU3-

6850001 under the frame of Neuron Cofund) and by the Programme International de Collaboration Scientifique (PICS 08212) of the CNRS. AEB was supported by the Labex EpiGenMed (program « Investissements d'avenir ", ANR-10-LABX-12-01).

\section{References}

1. Copeland R. A., Pompliano D. L. \& Meek T. D. Drugtarget residence time and its implications for lead optimization. Nat. Rev. Drug Discov. 2006;5:730-9.

2. Hoffmann C., Castro M., Rinken A., Leurs R., Hill S.

695 J. \& Vischer H. F. Ligand Residence Time at Gprotein-coupled receptors - Why we should take our time to study it. Mol. Pharmacol. 2015;88: 552-60.

3. Swinney D. C. Applications of binding kinetics to drug discovery. Pharmaceut. Med. 2008;22:23-34.

700 4. Lu H. \& Tonge P. J. Drug-target residence time: critical information for lead optimization. Curr. Opin. Chem. Biol. 2010;14:467-74.

5. Guo D., Hillger J. M., IJzerman A. P. \& Heitman L. H. Drug-target residence time - A case for $G$ Protein-

705 Coupled Receptors. Med. Res. Rev. 2014;34:85692.

6. Lefkowitz R. J., Roth J., \& Pastan I. Radioreceptor assay of adrenocorticotropic hormone: new 
710 plasma. Science. 1970;170:633-5.

7. Pert C. B. \& Snyder S. H. Opiate receptor demonstration in nervous tissue. Science. 1973;179:1011-3.

8. Sridharan R., Zuber J., Connelly S. M., Mathew E. \& 715 Dumont M. E. Fluorescent approaches for understanding interactions of ligands with $G$ protein coupled receptors. Biochim. Biophys. Acta. 2014;1838:15-33

9. Hovius R., Vallotton P., Wohland T. \& Vogel H. 720 Fluorescence techniques: shedding light on lighyreceptor interactions. Trends Pharmacol. Sci. 2000;21:266-73.

10. Zwier J. M., Roux T., Cottet M., Durroux T., Douzon S., Bdioui S., Gregor N., Bourrier E., Oueslati N., 725 Nicolas L., Tinel N., Boisseau C., Yverneau P., Charrier-Savournin F., Fink M. \& Trinquet E. A fluorescent ligand-binding alternative using Tag-lite ${ }^{\circledR}$ technology. J. Biomol. Screen. 2010;15:1248-59.

11. Zepperitz C., Höfner G. \& Wanner K. T. MS-binding 730 assays: kinetic, saturation, and competitive experiments based on quantitation of bound marker as exemplified by the GABA transporter mGAT1. ChemMedChem. 2006;1:208-17.

12. Hess M., Höfner G. \& Wanner K. T. (S)- and (R)735 fluoxetine as native markers in mass spectrometry (MS) binding assays addressing the serotonin transporter. ChemMedChem. 2011;6:1900-8.

13. Hess M., Höfner G. \& Wanner K. T. Development and validation of a rapid LC-ESI-MS/MS method for 740 quantification of fluoxetine and its application to MS binding assays. Anal. Bioanal. Chem. 2011;400:3505-15.

14. Schmitt S., Höfner G. \& Wanner K. T. MS transport assays for $Y$-aminobutyric acid transporters an

745 Eeficient alternative for radiometric assays. Anal. Chem. 2014;86:7575-83.

15. Grimm S. H., Höfner G. \& Wanner K. T. Development and validation of an LC-ESI-MS/MS method for the triple reuptake inhibitor indatraline 750 enabling its quantification in MS binding assays. Anal. Bioanal. Chem. 2015;407:471-85.

16. Grimm S. H., Höfner G. \& Wanner K. T. MS binding assays for the three monoamine transporters using

the triple reuptake inhibitor $(1 \mathrm{R}, 3 \mathrm{~S})$-indatraline as 755 native marker. ChemMedChem. 2015;10:1027-39.

17. Schuller M., Höfner G. \& Wanner K. T. Simultaneous multiple MS binding assays addressing D1 and D2 dopamine receptors. ChemMedChem. 2017;12:1-11.

760 18. Sichler S., Höfner G., Rappenglück S., Wein T., Niessenb K. V., Seeger T., Worek F., Thiermann H., Paintner F.F. \& Wanner K. T. Development of MS binding assays targeting the binding site of MB327 at the nicotinic acetylcholine receptor. Toxicol. Lett.

765 2018;293:172-83.

19. Neiens P., De Simone A., Ramershoven A., Höfner G., Allmendinger L. \& Wanner K. T. Development and validation of an LC-ESI-MS/MS method for the quantification of D-84, reboxetine, and citalopram for 770 their use in MS binding assays addressing the monoamine transporters hDAT, hSERT, and hNET. Biomed. Chromatogr. 2018;32:e4231.

20. Neiens P., De Simone A. Höfner G. \& Wanner K. T. Simultaneous multiple MS binding assays for the

775 Dopamine, Norepinephrine, and Serotonin transporters. ChemMedChem. 2018;13:453-63.

21. Massink A., Holzheimer M., Hölscher A., Louvel J., Guo D., Spijksma G., Hankemeier T. \& IJzerman A. $P$. Mass spectrometry-based ligand binding assays 780 on adenosine $\mathrm{A} 1$ and $\mathrm{A} 2 \mathrm{~A}$ receptors. Purinergic Signal. 2015;11:581-594.

22. Rossato M., Miralles G., M'Kadmi C., Maingot M., Amblard M., Mouillac B., Gagne D., Martinez J., Subra G., Enjalbal C. \& Cantel S. Quantitative 785 MALDI-MS Binding Assays: An alternative to Radiolabeling. ChemMedChem. 2016;11:2582-7

23. Cheignon C., Cordeau E., Prache N., Cantel S., Martinez J., Subra G., Arnaudguilem C., Bouyssiere B. \& Enjalbal C. Receptor-ligand interaction 790 measured by Inductively Coupled Plasma Mass Spectrometry and selenium labeling. J. Med. Chem. 2018;61:10173-84.

24. Nasrallah, C., Rottier, K., Marcellin, R., Compan, V., Font, J., Llebaria, A., Pin J. P., Banères J. L. \& 795 Lebon $G$. Direct coupling of detergent purified human mGlu5 receptor to the heterotrimeric $\mathrm{G}$ proteins $\mathrm{Gq}$ and Gs. Sci. Rep. Nature. 2018;8:4407.

25. Niswender C. M. \& Conn P. J. Metabotropic 
glutamate receptors: physiology, pharmacology, and

800 disease. Annu. Rev. Pharmacol. Toxicol. 2010;50:295-322.

26. Nicoletti F., Bockaert J., Collingridge G. L., Conn P. J., Ferraguti F., Schoepp D. D., Wroblewski J. T. \& Pin J.P. Metabotropic glutamate receptors: from the 805 workbench to the bedside. Neuropharmacology. 2011;60:1017-41.

27. Pereira, V. \& Goudet, C. Emerging trends in pain modulation by Metabotropic Glutamate Receptors. Front. Mol. Neurosci. 2018;11:464.

810 28. Walker, A. G. \& Conn, P. J. Group I and group II metabotropic glutamate receptor allosteric modulators as novel potential antipsychotics. Curr. Opin. Pharmacol. 2015;20:40-5.

29. Marszalek-Grabska M., Gibula-Bruzda E., Bodzon815 Kulakowaka A., Suder P., Gawel K., Talarek S., Listos J., Kedzierska E., Danysz W. \& Kotlinska J. H. ADX-47273, a mGlu5 receptor positive allosteric modulator, attenuates deficits in cognitive flexibility induced by withdrawal from 'binge-like' ethanol 820 exposure in rats. Behav. Brain Res. 2018;338:9-16.

30. Felts A. S., Bollinger K. A., Brassard C. J., Rodriguez A. L., Morrison R. D., Scott Daniels J., Blobaum A. L., Niswender C. M., Jones C. K., Conn P. J., Emmitte K. A. \& Lindsley C. W. Discovery of 4825 alkoxy-6-methylpicolinamide negative allosteric modulators of metabotropic glutamate receptor subtype 5. Bioorg. Med. Chem. Lett. 2019;29:47-50.

31. Cavallone L. F., Montana M. C., Frey K., Kallogjeri D., Wages J. M., Rodebaugh T. L., Doshi T., 830 Kharasch E. D. \& Gereau R. W. The metabotropic glutamate receptor 5 negative allosteric modulator fenobam: pharmacokinetics, side effects, and analgesic effects in healthy human subjects. Pain. 2020;161:135-146.

835 32. Gasparini F., Lingenhöhl K., Stoehr N., Flor P. J., Heinrich M., Vranesic I., Biollaz M., Allgeier H., Heckendorn R., Urwyler S., Varney M. A., Johnson E. C., Hess S. D., Rao S. P., Sacaan A. I., Santori E. M., Veliçelebi G. \& Kuhn R. 2-Methyl-6840 (phenylethynyl)-pyridine (MPEP), a potent, selective and systemically active mGlu5 receptor antagonist. Neuropharmacology. 1999;38:1493-503.

33. Nagel J., Greco S., Parsons C. G., Flik G., Tober C.,
Klein K. U. \& Danysz W. Brain concentrations of 845 mGluR5 negative allosteric modulator MTEP in relation to receptor occupancy - Comparison to MPEP. Pharmacol. Rep. 2015;67:624-30.

34. Felts A. S., Rodriguez A. L., Morrison R. D., Venable D. F., Manka J. T., Bates B. S., Blobaum A.

850 L., Byers F. W., Daniels J. S., Niswender C. M., Jones C. K., Conn P. J., Lindsley C. W. \& Emmitte K. A. Discovery of VU0409106: A negative allosteric modulator of mGlu5 with activity in a mouse model of anxiety. Bioorg. Med. Chem. Lett. 2013;23:5779-85

855 35. Alagille D., Baldwin R. M., Roth B. L., Wroblewski J. T., Grajkowska E. \& Tamagnan G. D. Synthesis and receptor assay of aromatic-ethynyl-aromatic derivatives with potent mGluR5 antagonist activity. Bioorg. Med. Chem. 2005;13:197-209.

860 36. Xu Z., Lou Y., Chen L., Zeng K., Sun Q \& Lei X. WO 2019144765.

37. Porter R. H., Jaeschke G., Spooren W., Ballard T. M., Büttelmann B., Kolczewski S., Peters J. U., Prinssen E., Wichmann J., Vieira E., Mulhemann A.,

865 Gatti S., Mutel V. \& Malherbe P. Fenobam: a clinically validated nonbenzodiazepine anxiolytic is a potent, selective, and noncompetitive mGlu5 receptor antagonist with inverse agonist activity. J. Pharmacol. Exp. Ther. 2005;315:711-21.

870 38. US Department of Health and Human Services Food and Drug Administration. Guidance for industry: bioanalytical method validation, https://www.fda.gov/media /70858/download 


\section{Figures, scheme \& tables}

875
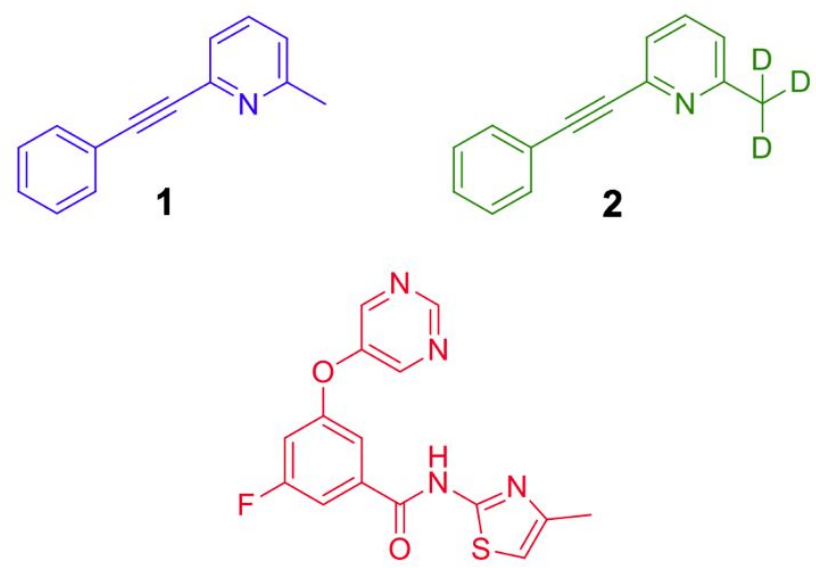

3

880

Figure 1. Chemical structures of molecules used for binding experiments. Structures of ligand marker MPEP (2-methyl-6(phenylethynyl)pyridine) (1) synthesized in MCS group according to described conditions in the literature [35], deuterated MPEP (or MCS0455) (2) used as internal standard and VU0409106 (3) used for determination of non-specific binding in MS binding assays.

885

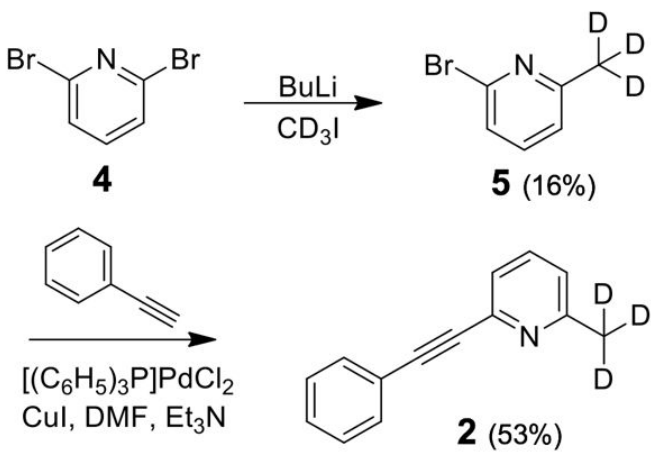

890

Scheme 1. Synthetic route to prepare MCS0455 (2). 

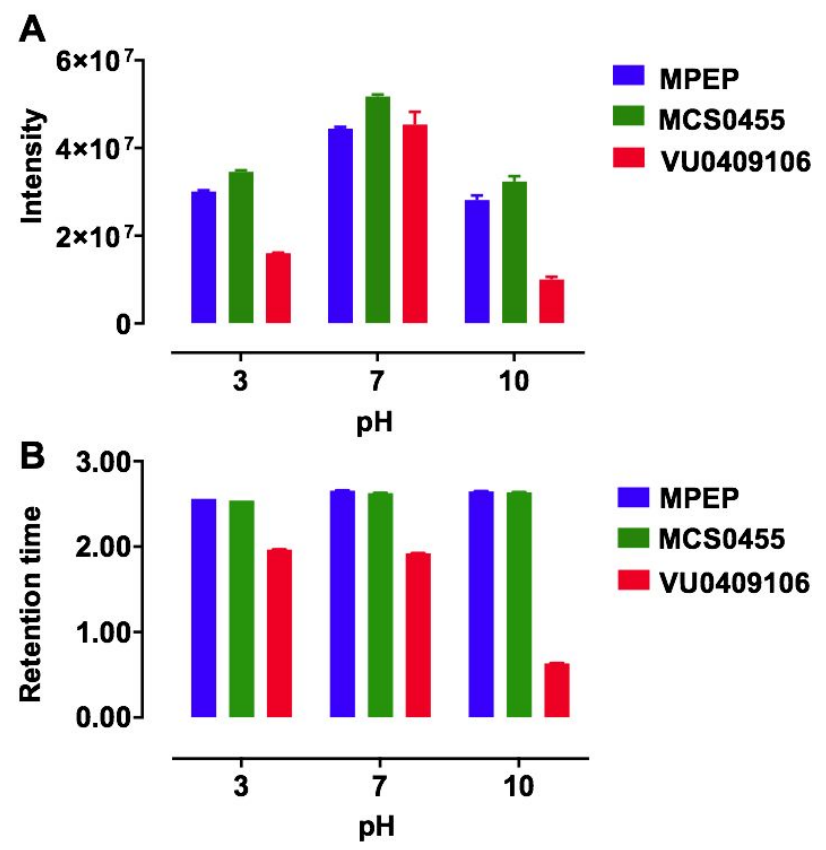

Figure 2. Influence of the aqueous phase $\mathrm{pH}$ on signal intensity and retention time of MPEP, MCS0455 and VU0409106. $\mathrm{pH}$ 895 values are plotted against (A) intensity, defined as peak area (m/z 194.1 for MPEP, m/z 197.1 for MCS0455 and m/z 331.1 for VU0409106) and (B) retention time of $50 \mathrm{mM}$ of each compound (means $\pm \mathrm{SEM}, \mathrm{n}=4$ ).

900
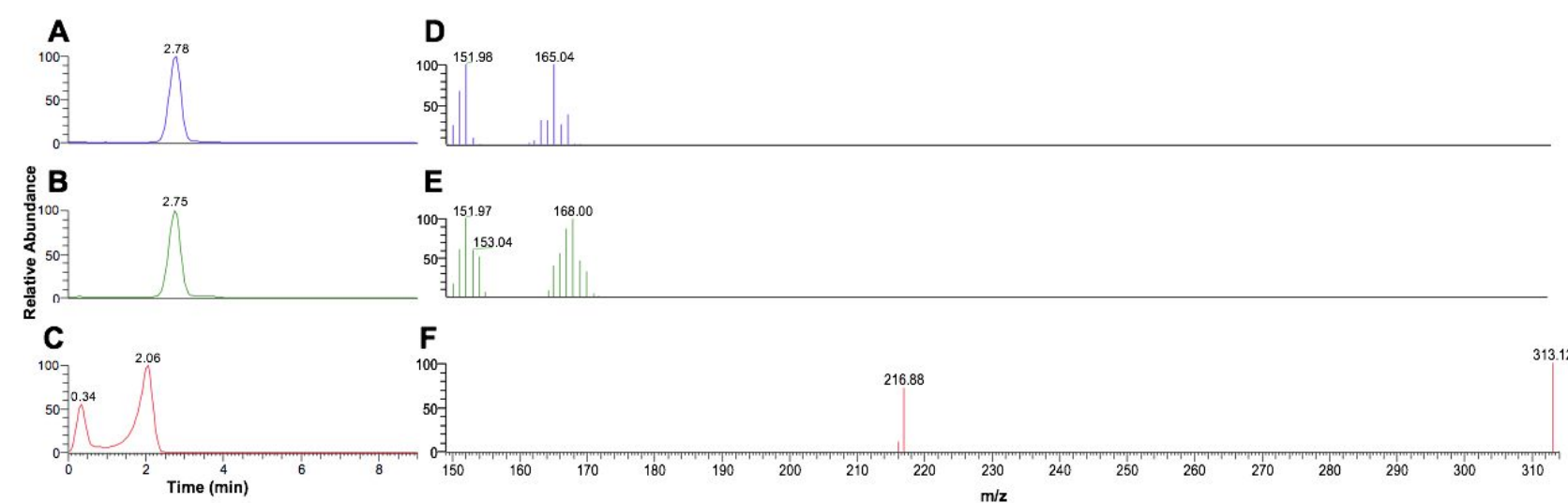

Figure 3. MRM chromatograms and production scan spectra of MPEP (blue), MCS0455 (green) and VU0409106 (red). MRM chromatogram and product ion scans in ESI (+) mode for m/z $152 \pm 6$ and $165 \pm 8$ of MPEP (A, D), m/z $152 \pm 6$ and $168 \pm 8$ for MCS0455 (B, E) and m/z $216 \pm 2$ and $313 \pm 2$ for VU0409106 (C, F) at a concentration of $5 \mathrm{nM}$ dissolved in $10 \mathrm{mM}$ ammonium bicarbonate $\mathrm{pH} 7$ : acetonitrile at ratio of 1:3. 910 
Table 1. Within- and between-run accuracy and precision of HPLC-MS/MS method to determine MPEP signal ( $\mathrm{n}=3 \mathrm{r}, 6$ replicates per run). Quality control (QC) samples with final concentrations of $0.125 \mathrm{nM}$ (Lower limit of quantification; LLOQ), $0.35 \mathrm{nM}$ 915 (Lower; L), $10 \mathrm{nM}$ (Medium; M), $20 \mathrm{nM}$ (Higher; H) and $25 \mathrm{nM}$ (Upper limit of quantification; ULOQ) were prepared in acetonitrile : $10 \mathrm{mM}$ ammonium bicarbonate, $\mathrm{pH} 7$ (3:1). The criteria for the data included accuracy (relative error, RE) and a precision (relative standard deviation, RSD) within $\pm 20 \%$ (except $\pm 25 \%$ for the LLOQ and ULOQ).

\begin{tabular}{|c|c|c|c|c|c|c|c|c|}
\hline & \multicolumn{4}{|c|}{ Within-run } & \multicolumn{4}{c|}{ Between-run } \\
\hline $\begin{array}{c}\text { Spiked } \\
\text { concentration } \\
\text { (nM) }\end{array}$ & $\begin{array}{c}\text { Technician } \\
\text { Accuracy } \\
\text { (RE, \%) }\end{array}$ & $\begin{array}{c}\text { HPLC-MS } \\
\text { Accuracy } \\
\text { (RE, \%) }\end{array}$ & $\begin{array}{c}\text { Technician } \\
\text { Precision } \\
\text { (RSD, \%) }\end{array}$ & $\begin{array}{c}\text { HPLC-MS } \\
\text { Precision } \\
\text { (RSD, \%) }\end{array}$ & $\begin{array}{c}\text { Technician } \\
\text { Accuracy } \\
\text { (RE, \%) }\end{array}$ & $\begin{array}{c}\text { HPLC-MS } \\
\text { Accuracy } \\
\text { (RE, \%) }\end{array}$ & $\begin{array}{c}\text { Technician } \\
\text { Precision } \\
\text { (RSD, \%) }\end{array}$ & $\begin{array}{c}\text { HPLC-MS } \\
\text { Precision } \\
\text { (RSD, \%) }\end{array}$ \\
\hline 0.125 & 15.6 & 16.6 & 10.2 & 9.7 & 8.7 & 6.7 & 13.5 & 15.8 \\
\hline 0.35 & 15.6 & 14.0 & 11.0 & 5.6 & 7.0 & 9.0 & 11.7 & 8.6 \\
\hline 10 & 14.3 & 15.4 & 1.0 & 2.1 & 6.9 & 8.2 & 6.3 & 6.2 \\
\hline 20 & 15.4 & 18.9 & 1.6 & 8.1 & 5.3 & 8.6 & 8.2 & 10.6 \\
\hline 25 & 13.1 & 15.2 & 1.9 & 5.0 & 4.5 & 6.8 & 8.2 & 8.4 \\
\hline
\end{tabular}

925 Table 2. Recovery of L, M and H quality control (QC) extractions for MPEP, MCS0455 and VU0409106 ( $\mathrm{n}=3 \mathrm{r}, 3$ replicates per run). Extractions were determined by comparing the analytical results of samples from corresponding extracts of blanks spiked with the analyte post-extraction. Data are expressed as a percentage of recovery range for each QC level.

\begin{tabular}{|c|c|c|c|}
\hline \multicolumn{4}{|c|}{ \% Recovery range } \\
\hline Quality control & MPEP & MCS0455 & VU0409106 \\
\hline L & $96.4-121.6$ & $113.5-123.7$ & $97.9-111.4$ \\
\hline M & $93.9-107.8$ & $101.8-102.4$ & $70.2-103.9$ \\
\hline H & $102.5-103.7$ & $102.8-104.0$ & $82.3-99.7$ \\
\hline
\end{tabular}


935

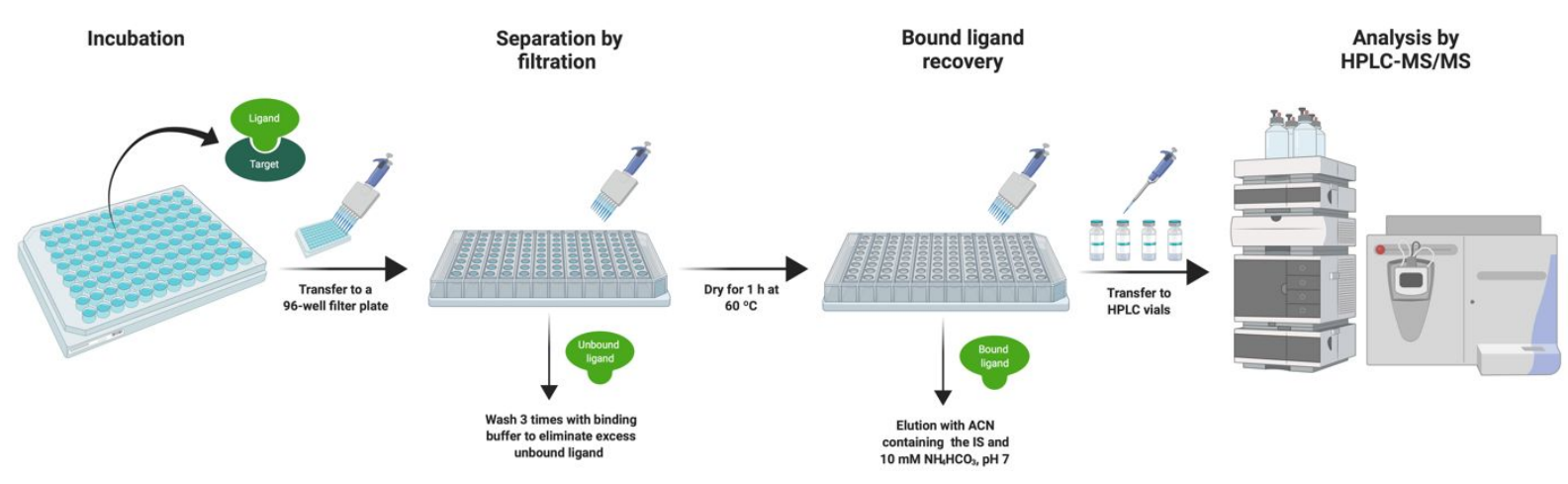

Figure 4. Flowchart of the protocol for the MS binding assay. For the saturation binding assay, hmGlu5 expressing membranes (20 $\mu \mathrm{g} /$ well) were incubated with a range of concentrations of MPEP in binding buffer for $1 \mathrm{~h}$ at $30^{\circ} \mathrm{C}$ while shaking at $150 \mathrm{rpm}$; final assay volume $300 \mu \mathrm{L} /$ well. Then, the target-ligand complex was separated from the non-binding ligand by rapid vacuum filtration through $1 \mu \mathrm{m}$ GF filter multi-well plate, pre-soaked for $1 \mathrm{~h}$ in $0.5 \% \mathrm{PEI}$, with an extraction plate manifold. Samples were washed 3 times with $150 \mu \mathrm{L}$ of 940 ice-cold binding buffer and the filter plate was dried for $1 \mathrm{~h}$ at $60^{\circ} \mathrm{C}$. The bound ligand was then recovered by filtration with acetonitrile containing the corresponding IS $(3 \times 100 \mu \mathrm{L} /$ well $)$ and $10 \mathrm{mM}$ ammonium bicarbonate buffer, $\mathrm{pH} 7.0(1 \times 100 \mu \mathrm{L} /$ well $)$. Samples were then transferred to HPLC vials and analyzed by HPLC-MS/MS methods. Non-specific binding was determined in the presence of $10 \mu \mathrm{M}$ VU0409106.

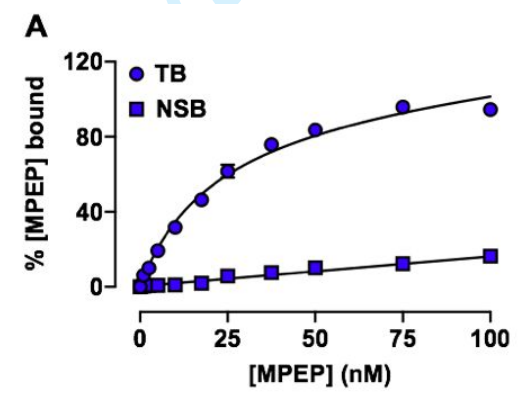

B

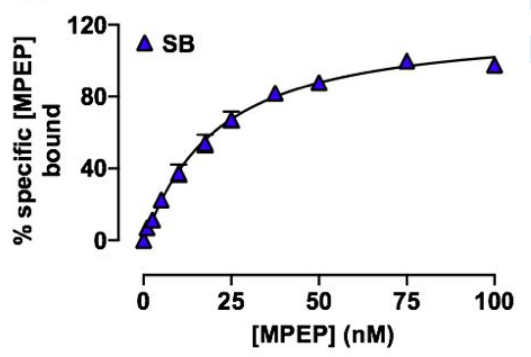

Figure 5. MPEP MS saturation binding study at mGlu5. Increasing concentrations of MPEP (1 to $100 \mathrm{nM}$ ) were incubated with 20 $950 \mu \mathrm{g} /$ well of membranes prepared from hmGlu5 expressing HEK cells for $1 \mathrm{~h}$ at $30^{\circ} \mathrm{C}$. (A) Data are expressed as a percentage of bound ligand and represent the mean \pm SEM of eight independent experiments performed in duplicate for total $(\circ)$ and non-specific binding ( $\square$ ). (B) Data are expressed as a percentage of bound ligand and represent the mean \pm SEM of eight independent experiments performed in duplicate for specific binding $(\triangle)$. Non-specific binding was determined in the presence of $10 \mu \mathrm{M}$ VU0409106. 


\title{
Analytical Bioanalytical Chemistry Supplementary information for
}

\section{Development and validation of a Mass Spectrometry binding assay for mGlu5 receptor}

\author{
Maria Ricart-Ortegaa ${ }^{a, c}$, Alice E. Berizzic ${ }^{c}$, Juanlo Catena ${ }^{a}$, Fanny Malhaire ${ }^{c}$, Lourdes Muñoz ${ }^{a, b}$, Carmen Serra $^{a, b}$, \\ Guillaume Lebonc, Cyril Goudetc, ${ }^{*}$ and Amadeu Llebariaa, ${ }^{*}$
}

aMCS, Laboratory of Medicinal Chemistry \& Synthesis, Department of Biological Chemistry, Institute for Advanced Chemistry of Catalonia (IQAC-CSIC), Barcelona, Spain; ${ }^{b}$ SIMchem, Service of Synthesis of High Added Value Molecules, Institute for Advanced Chemistry of Catalonia (IQAC-CSIC), Barcelona, Spain; 'IGF, CNRS, INSERM, University of Montpellier, F-34094 Montpellier, France.

* Amadeu Llebaria (ORCID: 0000-0002-8200-4827) and Cyril Goudet (ORCID: 0000-0002-8255-3535)

Email: amadeu.llebaria@iqac.csic.es and cyril.goudet@igf.cnrs.fr 
Supplementary Table 1. Within- and between-run accuracy and precision of HPLC-MS/MS method to determine MCS0455 signal ( $n=3$ r, 6 replicates per run). Quality control (QC) samples with final concentrations of $0.125 \mathrm{nM}$ (Lower limit of quantification; LLOQ), $0.35 \mathrm{nM}$ (Lower; L), $10 \mathrm{nM}$ (Medium; M), $20 \mathrm{nM}$ (Higher; H) and $25 \mathrm{nM}$ (Upper limit of quantification; ULOQ) were prepared in acetonitrile : $10 \mathrm{mM}$ ammonium bicarbonate, $\mathrm{pH} 7$ (3:1). The criteria for the data included accuracy (relative error, RE) and a precision (relative standard deviation, RSD) within $\pm 20 \%$ (except $\pm 25 \%$ for the LLOQ and ULOQ)

\begin{tabular}{|c|c|c|c|c|c|c|c|c|}
\hline & \multicolumn{4}{|c|}{ Within-run } & \multicolumn{5}{c|}{ Between-run } \\
\hline $\begin{array}{c}\text { Spiked } \\
\text { concentration } \\
\text { (nM) }\end{array}$ & $\begin{array}{c}\text { Technician } \\
\text { Accuracy } \\
\text { (RE, \%) }\end{array}$ & $\begin{array}{c}\text { HPLC-MS } \\
\text { Accuracy } \\
\text { (RE, \%) }\end{array}$ & $\begin{array}{c}\text { Technician } \\
\text { Precision } \\
\text { (RSD, \%) }\end{array}$ & $\begin{array}{c}\text { HPLC-MS } \\
\text { Precision } \\
\text { (RSD, \%) }\end{array}$ & $\begin{array}{c}\text { Technician } \\
\text { Accuracy } \\
\text { (RE, \%) }\end{array}$ & $\begin{array}{c}\text { HPLC-MS } \\
\text { Accuracy } \\
\text { (RE, \%) }\end{array}$ & $\begin{array}{c}\text { Technician } \\
\text { Precision } \\
\text { (RSD, \%) }\end{array}$ & $\begin{array}{c}\text { HPLC-MS } \\
\text { Precision } \\
\text { (RSD, \%) }\end{array}$ \\
\hline 0.125 & -16.8 & -12.8 & 18.7 & 16.6 & -7.2 & -7.6 & 13.5 & 12.4 \\
\hline 0.35 & 12.7 & 10.9 & 7.2 & 8.0 & 7.1 & 7.4 & 7.5 & 8.5 \\
\hline 10 & -5.6 & -4.8 & 3.7 & 1.7 & -1.2 & 0.1 & 3.4 & 4.2 \\
\hline 20 & -3.7 & 4.1 & 1.1 & 8.8 & -0.6 & 2.5 & 2.4 & 6.9 \\
\hline 25 & -5.8 & -3.2 & 1.8 & 6.7 & -4.2 & -0.7 & 2.0 & 5.4 \\
\hline
\end{tabular}

Supplementary Table 2. Within- and between-run accuracy and precision of HPLC-MS/MS method to determine VU0409106 signal ( $n=3 r, 6$ replicates per run). Quality control (QC) samples with final concentrations of $0.35 \mathrm{nM}$ (Lower limit of quantification; LLOQ), 1 nM (Lower; L), 10 nM (Medium; M), 20 nM (Higher; H) and 25 nM (Upper limit of quantification; ULOQ) were prepared in acetonitrile : 10 $\mathrm{mM}$ ammonium bicarbonate, $\mathrm{pH} 7$ (3:1). The criteria for the data included accuracy (relative error, RE) and a precision (relative standard deviation, RSD) within $\pm 20 \%$ (except $\pm 25 \%$ for the LLOQ and ULOQ).

\begin{tabular}{|c|c|c|c|c|c|c|c|c|}
\hline & \multicolumn{4}{|c|}{ Within-run } & \multicolumn{5}{c|}{ Between-run } \\
\hline $\begin{array}{c}\text { Spiked } \\
\text { concentration } \\
\text { (nM) }\end{array}$ & $\begin{array}{c}\text { Technician } \\
\text { Accuracy } \\
\text { (RE, \%) }\end{array}$ & $\begin{array}{c}\text { HPLC-MS } \\
\text { Accuracy } \\
\text { (RE, \%) }\end{array}$ & $\begin{array}{c}\text { Technician } \\
\text { Precision } \\
\text { (RSD, \%) }\end{array}$ & $\begin{array}{c}\text { HPLC-MS } \\
\text { Precision } \\
\text { (RSD, \%) }\end{array}$ & $\begin{array}{c}\text { Technician } \\
\text { Accuracy } \\
\text { (RE, \%) }\end{array}$ & $\begin{array}{c}\text { HPLC-MS } \\
\text { Accuracy } \\
\text { (RE, \%) }\end{array}$ & $\begin{array}{c}\text { Technician } \\
\text { Precision } \\
\text { (RSD, \%) }\end{array}$ & $\begin{array}{c}\text { HPLC-MS } \\
\text { Precision } \\
\text { (RSD, \%) }\end{array}$ \\
\hline 0.35 & 14.8 & 16.5 & 8.6 & 11.3 & 8.8 & 10.6 & 11.7 & 11.6 \\
\hline 1 & 12.3 & 14.6 & 4.7 & 7.8 & 8.0 & 10.2 & 7.6 & 8.5 \\
\hline 10 & -6.3 & 5.6 & 5.8 & 5.8 & -1.8 & 1.5 & 4.5 & 5.5 \\
\hline 20 & -5.3 & -5.3 & 2.3 & 6.4 & -2.4 & 1.3 & 2.7 & 6.5 \\
\hline 25 & -7.9 & -5.7 & 3.4 & 2.4 & -5.4 & -0.8 & 3.7 & 5.2 \\
\hline
\end{tabular}

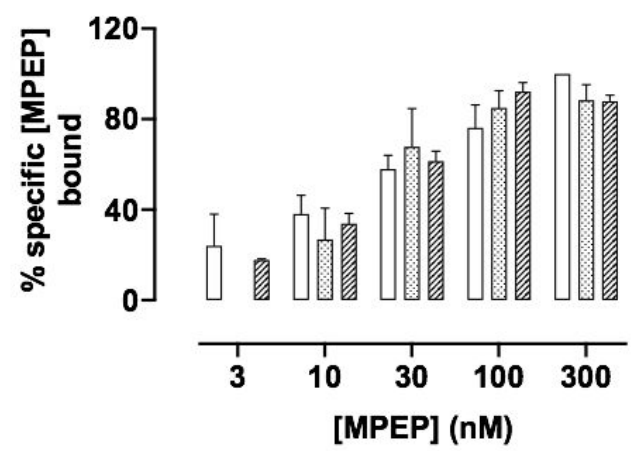

Supplementary Figure 1. The effect of different elution solvents on recovery of target-bound complexes and reproducibility between experiments. Increasing concentrations of MPEP ( 3 to $300 \mathrm{nM}$ ) were incubated with hmGlu5 expressing membranes ( $40 \mu \mathrm{g} / \mathrm{well}$ ) for $1 \mathrm{~h}$ at $30^{\circ} \mathrm{C}$. The separation of target-bound complex from unbound ligand was performed by filtration with 96-well filter plates, pretreated with $0.5 \% \mathrm{PEI}$. The bound ligand was then recovered by elution with different solvents, including $100 \%$ methanol, $75 \%$ acetonitrile and $25 \%$ ammonium formate buffer $(5 \mathrm{mM}, \mathrm{pH} 10)$, or $75 \%$ acetonitrile and $25 \%$ ammonium bicarbonate buffer (10 mM, pH 7). Data are expressed as percentage of specific bound ligand and represent the mean \pm SEM of at least three experiment performed in duplicate. Nonspecific binding was determined in the presence of $10 \mu \mathrm{M}$ M-MPEP. 


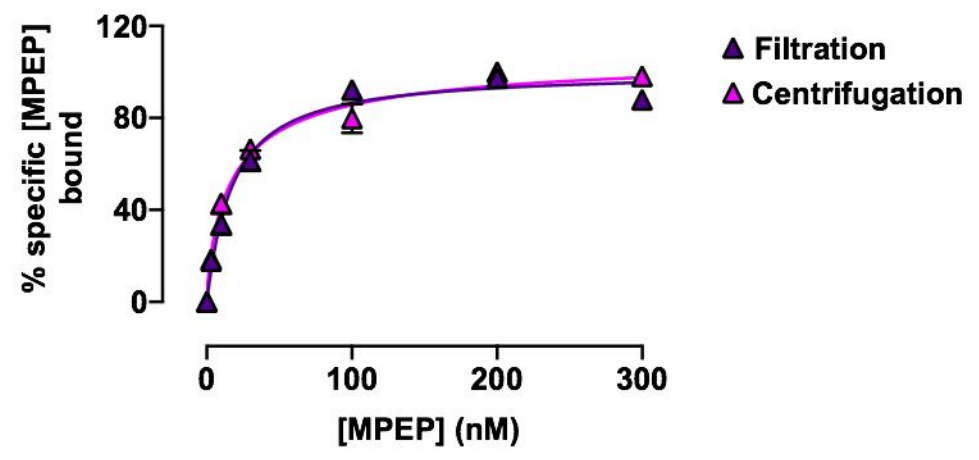

Supplementary Figure 2. The effect of filtration or centrifugation on recovery of target-bound complexes and reproducibility between experiments. Increasing concentrations of MPEP ( 3 to $300 \mathrm{nM})$ were incubated with hmGlu5 expressing membranes (40 $\mu \mathrm{g} / \mathrm{well})$ for $1 \mathrm{~h}$ at $30^{\circ} \mathrm{C}$. The separation of target-bound complex from unbound ligand was done with a 96-well filter plate, pre-treated with $0.5 \%$ PEI. Acetonitrile was then added to each well $(3 \times 100 \mu \mathrm{L} /$ well) and the bound ligand was recovered by filtration. Subsequently, $10 \mathrm{mM}$ ammonium bicarbonate buffer, $\mathrm{pH} 7$ was added to each well $(1 \times 100 \mu \mathrm{L} /$ well) and the solution was filtered (30 s aspiration step) or centrifuged $\left(10 \mathrm{~min}, 2000 \mathrm{rpm}, 4^{\circ} \mathrm{C}\right.$ ) before the samples were analysed according to the HPLC-MS/MS method. Data are expressed as percentage of specific bound ligand and represent the mean \pm SEM of at least two experiment performed in duplicate. Nonspecific binding was determined in the presence of $10 \mu \mathrm{M}$ M-MPEP.

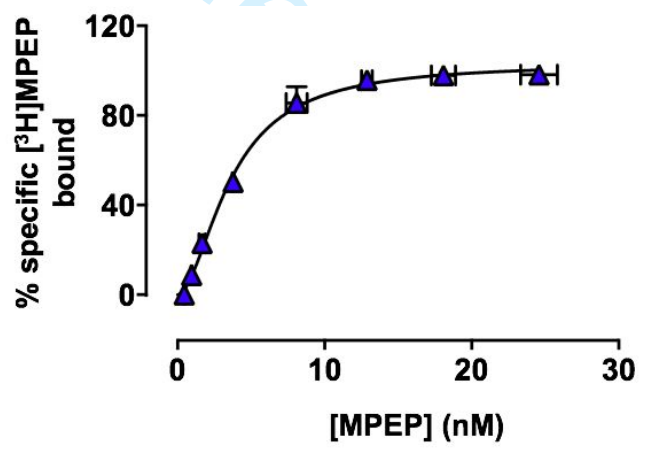

Supplementary Figure 3. [3 ${ }^{3}$ ]MPEP equilibrium saturation binding study at mGlu5. $10 \mu \mathrm{g}$ of membranes prepared from hmGlu5 expressing HEK cells were incubated with increasing concentrations of $\left.{ }^{3} \mathrm{H}\right] \mathrm{MPEP}$ for $1 \mathrm{~h}$ at $30^{\circ} \mathrm{C}$. Data are expressed as a percentage of specific binding and represent the mean \pm SEM of three independent experiments performed in duplicate. Nonspecific binding was determined in the presence of $10 \mu \mathrm{M}$ MPEP.

Supplementary Table 3. Summary of MPEP $K_{D}$ (equilibrium dissociation constant) and $B_{\max }$ (maximum amount of binding sites) estimates as determined by $\left[{ }^{3} \mathrm{H}\right] \mathrm{MPEP}$ equilibrium saturation binding assay.

\begin{tabular}{|c|c|c|}
\hline Allosteric ligand & $\mathbf{K}_{\mathbf{D}}(\mathbf{n M})$ & $\mathbf{B}_{\max }$ (fmol/mg protein) \\
\hline$\left[{ }^{3} \mathrm{H}\right] \mathrm{MPEP}$ & $3.65 \pm 0.32$ & $1777 \pm 72.05$ \\
\hline
\end{tabular}

